\title{
Intersectional Organizing and Educational Justice Movements: Strategies for Cross- Movement Solidarities
}

\author{
Mark R. Warren, University of Massachusetts Boston \\ Patricio Belloy, University of Massachusetts Boston \\ Andrew King, University of Massachusetts Boston \\ Bianca Ortiz-Wythe, University of Massachusetts Boston \\ Jose Zapata Calderon, Pitzer College \\ Pam Martinez, Padres \& Jóvenes Unidos
}

Mark R. Warren is Professor of Public Policy and Public Affairs at the University of Massachusetts Boston. A sociologist and community engaged scholar, Warren is author of several books, most recently Lift us up Don't push us out! Voices from the Front Lines of the Educational Justice Movement (Beacon Press, 2018).

Andrew R. King is a doctoral candidate at the University of Massachusetts Boston. His dissertation explores community organizing and family empowerment in New York City's Community Schools Initiative. He is coauthor of "Our Stories Are Powerful: The Use of Youth Storytelling in Policy Advocacy to Combat the School-to-Prison Pipeline" (Harvard Education Review).

Bianca Ortiz-Wythe is a doctoral candidate in Public Policy at the University of Massachusetts Boston. Her research explores the impact of "deportability" on undocumented and asylum-seeking parents from Central America. Currently, she is organizing with her neighbors against food insecurity and housing instability in her neighborhood in Boston.

Patricio Belloy is $\mathrm{PhD}$ candidate in Public Policy at the University of Massachusetts Boston. He studies policy instruments at the intersection of racial, economic, and social inequities and climate change. Belloy was awarded an MIT Mel King Community Fellowship for his work promoting renewable energy education in vocational-technical schools in Southern Chile.

Jose Zapata Calderon is Emeritus Professor in Sociology and Chicano/a Latino/a Studies at Pitzer College. As the son of immigrant farm workers from Mexico, he has had a long history of connecting his organizing and academic work with community-based teaching, participatory action research, critical pedagogy, and engagement.

Pam Martinez is cofounder and former codirector of Padres \& Jóvenes Unidos (Parents and Youth United) in Denver, Colorado. She is the author of "The freedom to learn: Dismantling the school-toprison pipeline in the Southwest," in Lift us up Don't push us out! Voices from the Front Lines of the Educational Justice Movement.

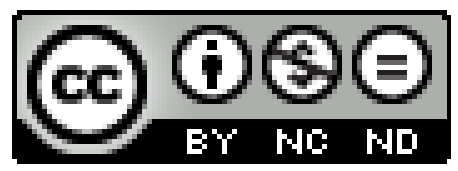

See: https://creativecommons.org/licenses/by-nc-nd/4.0/ 


\begin{abstract}
This article explores intersectional organizing as a strategy to create solidarity across issues, organizations and communities to build a more united educational justice movement. By intersectional organizing, we mean an organizing strategy that centers the experiences and leadership of people who are affected by multiple forms of oppression. We conducted interviews with ten community organizers who engage parents and young people of color to address the profound inequities in public education. We found that the movement is largely siloed into separate issue-based campaigns, although there are promising examples that connect groups and issues. Organizers believe that intersectional organizing can support greater cross-movement solidarity especially when combined with other processes, including building deep relationships, developing conscious leadership with shared understandings of systemic oppression through political education, and building trust through demonstrated long-term commitments to solidarity in practice. Nevertheless, many warn against an "Oppression Olympics" that creates competition rather than solidarity.
\end{abstract}

Keywords: intersectionality, community organizing, educational justice, racial equity 


\title{
Intersectional Organizing and Educational Justice Movements: Strategies for Cross- Movement Solidarities ${ }^{1}$
}

\author{
Mark R. Warren, University of Massachusetts Boston \\ Patricio Belloy, University of Massachusetts Boston \\ Andrew King, University of Massachusetts Boston \\ Bianca Ortiz-Wythe, University of Massachusetts Boston \\ Jose Zapata Calderon, Pitzer College \\ Pam Martinez, Padres \& Jóvenes Unidos
}

\begin{abstract}
I think it's an absolute necessity for all folks who are organizing for social change to have the concept in mind and practice it, that we have to intersect and that we have to come together. Because if we don't, we're gonna fail... So the education justice movement has to link up with other movements around the country that are fighting gentrification, that are fighting against police brutality, that are fighting for fair wages for people. We have to do that because that's our community.

Those are our families.

-- Ricardo Martinez, Padres \& Jóvenes Unidos
\end{abstract}

There is a new urgency for grassroots organizing efforts and social justice movements to connect and support one another in the current political era. The rise of conservative and white supremacist forces threatens all progressive movements, from Black lives and public education to the rights of undocumented people and women's reproductive rights. If movements do not win together, they are likely to lose on their own.

The contemporary educational justice movement is no different. It faces the need to create new forms of solidarity to build the broader base of grassroots power necessary to address the multiple, intersecting forms of oppression faced by low-income children of color and their families. By the educational justice movement, we mean grassroots organizing efforts that build the participation and leadership of those most affected by racial and educational injustices to advocate for equity-oriented policy change in alliance with legal advocacy groups, educators and other actors (Warren, 2018). Education organizing groups' campaigns focus on goals such as, but not limited to, ending racially discriminatory discipline and policing practices; stopping the mass closure of public schools in Black and Brown communities; diverting funds from the mass incarceration system to public education and community development; and creating communityoriented schools with culturally-relevant curriculum for students, restorative practices, and respectful, inclusive, and participatory cultures for students and families (Warren, 2018).

In regard to the theme of this special issue, place and displacement, we understand processes of gentrification to be systemically tied to the privatization of public education and a prime example of how issues intersect in the lives of students and families in low-income communities of color. Gentrification and school privatization are both part of a broader neoliberal agenda for the transformation of cities and its public institutions, such as public

\footnotetext{
${ }^{1}$ For helpful comments on earlier versions of this article, the authors would like to thank participants at the 2019 People's Think Tank meeting, the 2019 meeting of the Urban Research Based Action Network, and the 2019 meeting of the American Sociological Association, as well as Veronica Terriquez, Ben Kirshner, Antwan Jefferson, and the editors and reviewers of this special issue. Partial support for this research was provided by the Ford Foundation.
} 
education (Ewing, 2018; Lipman, 2011). In other words, the same corporate interests that push residents of low-income communities of color out of their neighborhoods to make way for white and middle class gentrifiers are also behind efforts to close public schools that serve Black and Brown communities and open charter schools that often become schools of choice for white gentrifier families (Buras, 2014; Wilson, 2015). Organizing groups such as the Journey for Justice Alliance (2014) argue that, rather than close struggling schools, state and local authorities should invest in them and create sustainable community schools, which would then serve as anchors for low-income residents who could remain in their neighborhoods. Organizing efforts like these that fight school closings and the transformation of public schools into corporatemanaged charter schools would benefit from alliances of mutual support with organizations that are fighting gentrification and advocating for affordable housing and sustainable communities. Yet the two movements typically organize in separation from each other.

A similar point could be made about connecting educational justice to movements that address immigrant and undocumented students' rights or homelessness. Few movements seek to address the full range of ways young people and communities are displaced. Indeed, the educational justice movement taken as a whole remains largely siloed. Groups typically focus on one issue, such as ending the school-to-prison pipeline, or on one constituency, such as parents, students, or queer and trans youth.

In this paper we examine intersectional organizing as a strategy for groups organizing for educational justice to break out of their silos and build solidarity within the educational justice movement and across other movements. By intersectionality, we mean an understanding of the way different types or lines of oppression intersect in people's lives, shaping their experiences and identities in unique ways, and calling forth different kinds of responses; by intersectional organizing, we mean an organizing strategy that centers the experiences and leadership of people who are affected by these multiple systems of oppression (Kunreuther \& Thomas-Breitfeld, 2015). We consider this an exploratory study in an area that has received very little scholarly attention.

The authors of this paper are activist scholars and organizers involved with the People's Think Tank (PTT). The PTT is a network of educational justice movement organizers who came together to produce a book of essays on grassroots organizing strategies called Lift Us Up, Don't Push Us Out! (Warren, 2018). The PTT is now a forum for organizers to conduct research and build knowledge to develop new strategies to strengthen and expand their organizing work. PTT members believe a key obstacle to movement building is the siloed nature of organizing efforts and asked us to study whether and how intersectional organizing contributes to cross-issue solidarity. We started our research by interviewing a set of organizers in the PTT in order to learn from the experience and knowledge of practitioners on the ground (Fine, 2018), and we report our findings in this article.

\section{Intersectionality in Social Theory}

Intersectionality is perhaps most developed as an analytical tool or theory for understanding social identity and marginalization (Collins, 2019). Intersectional approaches have had important implications for social movements because they have identified the silencing and invisibility of people facing intersectional identities and experiences, such as Black women, who use intersectional approaches to demand voice and inclusion. However, the potential of intersectional approaches to create cross-movement solidarity is not as well developed. 


\section{Intersectionality as Social Analysis}

Black feminist legal scholar Kimberlé Crenshaw (1990) first coined the term intersectionality to describe the double oppression faced by Black women. Crenshaw argued that traditional understandings of discrimination centered the experiences of Black men or white women, effectively erasing the unique experiences of Black women who live on the margins in each group. Crenshaw posited that the intersectional nature of Black women's identities is more than the simple sum of their race plus their gender, which doesn't capture the particularity and full complexity of their lived experience.

African American sociologist Patricia Hill Collins (2000) developed intersectionality as a theory and an analytical lens to examine complex social institutions and systems of oppression. She proposed the matrix of domination to show how oppressive systems intersect to marginalize people in different ways. Collins argues that this matrix explains how power works in society along multiple intersecting axes, rather than through one primary form of oppression. Collins discussed how intersectional analysis can form the basis for social justice movements as people and communities form solidarity across the matrix (Collins, 2019; Collins \& Bilge, 2016). While Collins also focused on the experiences of Black women, intersectionality applies to other forms of oppression and intersections including in relation to class, sexual orientation, gender identity, immigration status, and other dimensions of identity. For an example, see Anzaldúa (1987).

\section{Intersectional Organizing and Inclusive Movements}

The most direct roots of intersectionality, as advanced by Crenshaw and Collins, are located in the interaction of Black feminist theory and activism in the seventies and eighties, including, for example, the Combahee River Collective Statement (1986). Thus, intersectionality has long had a strong connection to social movements. Historically, the leadership of many social movements had been dominated by white, male and cisgender participants, leaving Black women and queer people of color excluded and their particular issues ignored (Cohen, 1999; Combahee River Collective, 1986). Using intersectional approaches, people at the intersections of multiple forms of oppression, such as Black women and queer people of color, have organized and asserted their voice and leadership in social movements and demanded that their issues be heard and addressed. Relatedly, intersectionality has come to mean interrogating power and privilege among movement activists because it recognizes that some people can be simultaneously privileged along some dimensions and oppressed along others, as is the case with Black men and white women (Fine, White, Pruitt, \& Burns, 2012).

The Black Lives Matter movement is perhaps the best-known example of how organizers use an intersectional approach to center the most marginalized members of their movement (Jackson, 2016; Lindsey, 2015; Rickford, 2016). In A Herstory of the \#BlackLivesMatter Movement, Alicia Garza (2014) describes how she and other Black, queer women organizers created the BLM hashtag and network to be inclusive of all Black life by including women and queer people who were historically marginalized within Black organizing spaces.

As people at the intersections of multiple oppressions or who identify with multiple marginalized groups assert their voice and leadership, they have critiqued movements for ignoring the ways particular issues affect them and have created new agendas. For example, police reform movements that only focus on the experience of police brutality against Black men do not address the sexual violence that Black women sometimes experience at the hands of police (Ritchie, 2017). Organizing efforts to combat the school to prison pipeline that focus solely on the experiences of Black and Brown boys do not address the specific forms of 
discipline and exclusion faced by girls of color and gender non-conforming students (Morris, 2018).

\section{Intersectional Organizing as the Basis for Cross-Movement Solidarity}

Using intersectionality for cross movement mobilization focuses attention on how intersecting experiences and identities have the potential to create solidarity and cohesion (Kunreuther \& Thomas-Breitfeld, 2015). According to intersectional thinking, movements can unite when they center people whose lived experiences and intersectional identities connect them to each other (Jackson, 2016; Rickford, 2016; Teuscher, 2015). This connection happens because activists with intersectional identities are located at the nexus of interlocking systems of oppression and are therefore strategically positioned to participate in, lead, and link different movements. Activists from multiply marginalized groups who have an intersectional consciousness, such as Black women who simultaneously address both gender and race oppression in their organizing, may be particularly motivated to exercise leadership and connect different movements (Terriquez, 2015). Moreover, intersectional analysis can help movements develop an analytical frame that links social movements across issues (Terriquez, Brenes, \& Lopez, 2018).

There is very limited scholarship, however, that examines this particular way to create cross-movement solidarity. In addition, intersectional organizing has become something of a buzz word, and people often mean different things when using the term (Kunreuther \& ThomasBreitfeld, 2015). As noted above, for us, intersectionality means an understanding of the way different types or lines of oppression intersect in people's lives - and how they respond to those intersections of oppression-shaping their experiences and identities in unique ways. By intersectional organizing we mean an organizing strategy that centers the experiences and leadership of people who are affected by these multiple systems of oppression. We will see that, while many organizers in the educational justice movement appreciate the benefit of an intersectional approach such as what we describe, some organizers have witnessed intersectionality serving to narrow and divide movements rather than unite them. In this context, we see this article as a beginning contribution to help clarify the role of intersectional organizing particularly in relationship to solidarity-building.

\section{Methods}

We consider our research to be an inductive, exploratory study designed to describe and analyze the understandings and practices of intersectional organizing within the educational justice movement. We decided to interview organizers who were members of the PTT as a starting point. Further study will be planned as the PTT develops.

We conducted in-depth, semi-structured interviews with eight community, parent and youth organizers in the PTT chosen to include diverse experiences in the educational justice movement. We also draw from in-depth, semi-structured interviews conducted earlier with two additional organizers in the PTT, some of the results of which were published in the anthology entitled Lift us up Don't push us out! (Warren, 2018). While we do not claim that these organizers represent the full range of educational justice organizing, we do believe they present a rich diversity of organizing efforts across the country (see appendix A for a list of the organizers). Nevertheless, there are few organizers under the age of thirty in the study and previous research suggests that younger organizers are more likely to take an intersectional 
approach to organizing (Milkman, 2017; Terriquez \& Lin, 2020). See Appendix B for a list of interview questions that formed the basis for each interview.

Each interview lasted about 60 minutes and was audio-taped and professionally transcribed. We then conducted thematic analysis of the interviews using an inductive process (Boyatzis, 1998). We identified the various ways that organizers define, understand and practice intersectional organizing; the processes that they believed were important to creating solidarity across issues and movements; and the concerns and critiques they had of intersectionality in the educational justice movement. In other words, while our literature review helped frame our study, we did not seek to test out propositions from that literature but rather focused on understanding intersectional organizing from the point of view and with the voices of the organizers.

We understand that the personal standpoints and experiences of researchers shape and limit the research process, no less in a study of intersectionality itself (Collins, 2000). We tried to include diversity in personal identity on our research team but we acknowledge that many intersecting identities are not included. Consequently, we offer this review humbly as part of a larger scholar and activist conversation to develop intersectional understanding and strategies for solidarity in the movement for educational justice and other social justice movements within and beyond the PTT.

\section{Embracing Intersectional Organizing}

In this and the following sections, we report the findings from our interviews and draw upon them for quotations to support our claims. We found that organizers in the educational justice movement embrace the core tenet of intersectional analysis: that the people they are organizing - parents and young people in low-income communities of color-experience multiple, intersecting forms of oppression. As Jonathan Stith, the national director of the youth organizing network Alliance for Educational Justice, quoting Audre Lorde, puts it: "they don't live single issue lives." In their organizing work with particular constituencies or around particular issues, organizers do undertake intersectional organizing as we have defined it: they center the lived experiences and foster the participation and leadership of the folks who are the most impacted by educational inequities along intersecting lines of injustice.

Following intersectional analysis, educational justice organizers work to create fully inclusive spaces. Kate McDonough, organizing director for Girls for Gender Equity, a group that organizes girls and gender nonconforming students of color in New York City, argues that it's not enough to just have marginalized community members "tell their stories"; they must be part of creating the solution "because they live it every day." As Sally Lee, the executive director of Teachers Unite, a group of activist public school teachers in New York City, notes:

The folks who are most directly impacted by an institution should have the decisionmaking power on those institutions. That's the principle of transformative justice/restorative justice we're talking about - transformation through struggle, collective leadership, collaboration, and all voices being heard.

For Maisie Chin, executive director of the parent organizing group CADRE in South Los Angeles, intersectional organizing is "a practice" that involves not just an awareness of all forms of oppression and their interconnections; it's about how to engage people whose lived experiences reflect those intersections. According to Chin, as they engage parents around education: 
We look at all the structural barriers that a parent may have that aren't related to education as well and figure out how to craft or design an approach for that person. We take everything into consideration so that they can be more honest about what they're going through and then that ripples into people sharing things about themselves that aren't related to education that impact what their kids may be going through.

Chin, like other organizers, addressed intersectionality as "critical consciousness," that is, a framework through which to interrogate power and privilege within themselves and/or systems of oppression. Chin wants to ensure that intersectionality means more than "the cataloging of all the issues and a listing and a shout out to every corresponding connected oppression." Rather, it must "allow us to deconstruct our power and privilege in any situation with any group of people."

\section{Challenges to Cross-Movement Solidarity}

While organizers have used intersectional approaches to center the experiences of those most impacted by injustice, create more inclusive movements, and address power and privilege within organizing, they mostly do so in silos with particular constituencies and issues. As noted earlier, educational justice movements remain focused on single issues or work with particular groups, even as organizers appreciate the need for solidarity. Organizers revealed several factors that tend to silo education justice organizing.

\section{The Felt Need for Separate Organizations}

As organizers have used intersectional analysis to demand voice and inclusion of those most marginalized, they have often felt the need to do so by building separate organizations for those constituencies. Otherwise, they fear they will be marginalized by the larger movement. Young people in Boston's Youth on Board youth organizing group, for example, often felt silenced in intergenerational movements and created their own youth organization to assert their voice and be heard. Parents of color have done the same. According to organizer Zakiya Sankara-Jabar, co-founder of Racial Justice NOW! in Dayton, Ohio, the group centers Black parents because "their voices are so often drowned out," even in the progressive movement, that they need their own "political home." She reports,

I can't tell you how many times I walk into spaces where we're supposed to be among allies, and I hear things about Black parents that make me cringe. There is not really a political home for parents, for Black parents, for Black and Brown parents or parents who are at the margins both economically and in other ways that are interconnected.

We heard about the need for independent spaces for particular communities to demand voice and inclusion in the larger educational justice movement repeatedly across the interviews.

The Genders and Sexualities Alliance Network (GSA Network) formed to support LGBTQ youth to have their own space to organize and be heard, which has allowed them to thrive. Girls for Gender Equity created a separate space to advocate for the particular issues of girls of color and gender nonconforming young people, which the group believes is critical to achieving its goals. Some groups such as Padres \& Jóvenes Unidos (PJU) in Denver organize intergenerationally and inclusively with trans and queer people. Yet even these groups often focus on one racialized group. In this case, PJU focuses on the Chicano/a-Mexicano/a community by addressing educational justice and immigrant rights among other issues. By 
focusing its work with this constituency, PJU works to bring awareness of the particular form of oppression they face in the larger educational and social justice movement where it feels it has not been fully appreciated (P. Martinez, 2018).

\section{Resource Constraints}

In addition to being siloed by constituency, the educational justice movement is also siloed by the typical focus of groups on single issues. In part, the narrow issue focus comes from the funding policies of private foundations that provide critical support to these groups, which are typically 501(c)3 nonprofit organizations. Foundations tend to fund groups to win specific policy changes or work in a particular issue area that aligns with the foundation's priorities. According to Sally Lee from Teachers Unite, these constraints require organizing groups "to create our little niche just to sustain ourselves." According to Ricardo Martinez from PJU, issuespecific funding "limits the conversation" about movement building. Martinez states, "It becomes movement building around youth organizing, movement building with immigration, movement building with human rights, movement building around gentrification. That's not building a broad movement." Organizers also believe that the increased focus on measurable results of funded programs has only strengthened the siloed nature of social justice organizing and narrowed the focus on specific policy change.

Even if a group adopts an intersectional analysis that appreciates how members live multi-issue lives along intersecting lines of oppression, they often end up engaged in organizing efforts one issue at a time. According to Carlos Rojas from Youth on Board, a youth organizing group in Boston,

I think most people enter organizing or enter into a rally or an activist space, thinking about a single issue. That was my case. I was in the immigrant youth space as a DREAMer... and then I would enter a Youth on Board space, take that hat off, and I would be a student in the Boston Public Schools and shape my story only around being a student.

Organizers also recognize that their organizations are typically small and lack the time and resources to address multiple issues at the same time. Rojas asks how young people are supposed to organize on multiple fronts when "they are already trying to figure out five different actions for education funding, and their school budgets are getting cut, and the school to prison pipeline is still raging on in their lives." Zakiya Sankara-Jabar appreciates the interconnected nature of the issues in people's lives but believes that groups must target one issue to make best use of limited resources and achieve results. As she states, "we just don't have the capacity to do it all."

The political institutions that are the targets of organizing campaigns are also siloed. In other words, education justice groups typically target school boards and district administrators while housing justice groups target city councils and housing authorities. In the end, intersectional organizing runs counter to the way political institutions are organized, which makes it challenging to adopt intersectional, multi-issue campaigns.

\section{Factors and Processes Promoting Solidarity}

Despite these challenges to intersectional solidarity, organizers have been able to create promising new forms of solidarity through an intersectional approach. Indeed, many organizers highlight educational justice and schools as a particularly good place to connect social issues. 
According to Natasha Capers from the Coalition for Educational Justice, a group led by parents of color in New York City, everything "coalesces in schools." She goes on to state:

Schools are one of the few places that all of the woes of the world live:

environmental justice, health justice, reproductive justice, food and security, all of those things. They all intersect within a school. Like transportation and health: students have asthma because they live next to the highway and there's not a hospital within any close distance and your school ain't got a nurse.

Some significant examples of solidarity based upon intersectional organizing emerged from our research. Even if they are small, some groups do manage to address multiple issues, and see this multi-issue organizing as a way to build greater power around any one issue. Jose Calderon, chairperson of the Latino/a Roundtable of the San Gabriel Valley and Pomona Valley outside of Los Angeles, recounts how the group links the immigrant rights and educational justice movements through organizing processes that center immigrant families and young people (see also the discussion of PJU in Martinez, 2018). Calderon shows how immigrant participants who grow into leadership around one issue campaign then become leaders in other campaigns. This process empowers them to cross back and forth between what are considered immigrant rights issues (e.g., drivers licenses for undocumented immigrants) and educational issues (e.g., community schools). Community power is built in this intersectional manner, leading to more victories in each domain.

Most groups, however, create solidarity across issues and constituencies by forming coalitions with other organizations. Maisie Chin relates the experience of what she calls an "intersectional movement building table". This coalition included nineteen groups addressing the multiple issues affecting families of color in South Los Angeles including health, housing, jobs, education, and the environment. According to Chin, it took ten years for groups to build a strong foundation for solidarity. They had to get past a history of competition over funding, develop a long-term strategy for community empowerment based upon a shared analysis about the centrality of anti-Black racism and criminalization of communities of color, support each other's issues, and eventually do shared work together, namely intersectional political education and resident engagement.

These examples suggest that creating solidarity based upon intersectional organizing is a process that takes more than just an understanding of how issues are interconnected in people's lives or centering leadership among those most impacted. In fact, for groups to work consistently in solidarity with each other, organizers in this study argued that it takes time to build relationships and trust, develop leadership with a shared understanding through political education and deeper analysis of the causes of systemic oppression, and overcome competition.

\section{Relationship-building, Understanding and Empathy}

Several organizers stress that creating solidarity among participants across movements and communities requires intentional relationship-building through sharing personal stories to create understanding and empathy. For example, Maisie Chin says CADRE makes sure "that intersectionality is not done in an elitist kind of way where it's about book knowledge or issue awareness, but really about connecting it to your story." Carlos Rojas emphasizes the importance of sharing stories in a healing space where participants can gain a deeper understanding of each other's experiences:

One of the most effective ways to get people to unpack their oppressive conditioning in order to practice full solidarity with other communities is getting to witness someone 
process or talk about or rage about or cry about their experience as a woman or their experience as an immigrant. It humanizes the issue. There's an emotional connection, and then you get to operate not from guilt but from really understanding the impact and the importance of embracing people and being in community with all kinds of people. Organizers often work hard to create empathy and understanding in the context of historical prejudices. According to Geoffrey Winder from the GSA Network:

When we engage the larger education reform movement to address the issues facing LGBTQ youth, many older folks find it challenging because it's very different from their lived experience. Part of intersectionality requires being in solidarity even when it isn't your direct life experience. You need to be able to understand the ways systems work simultaneously on multiple identities or be empathetic enough to understand why a group of people is looking for a solution to a problem and accept their truths on the issues that are most critical to them, even if they aren't your own.

Here, Winder is talking about the need for people to achieve systemic understanding, empathize with the life experiences of others, and also accept their claimed identities, that is, who they are. This requires patient, base-building work. Without that effort, according to Maisie Chin, organizers run the risk of marginalizing themselves by only engaging with people who agree with them and use similar terminology, thus alienating or excluding those who think differently but need to become part of the movement. For Chin, intersectionality is not just the latest buzzword, "It's really about the struggle to get there," which takes sustained commitment and effort.

\section{Political Education and Root Causes}

To counter prejudice and lack of knowledge within the movement, political education is just as important as sharing stories. Organizers cannot assume that people already have an understanding of the historical and contemporary oppression of groups and communities of which they are not members. Personal stories provide one way to mutual understanding and emotional connection, but participants in organizing also need a larger systemic analysis to see the connections across forms of oppression. For example, according to Maisie Chin, Latino/a immigrants who have moved into South Central Los Angeles are subject to the larger society's anti-Black racism that blames poor Black people for poverty. Thus, they "may or may not know about red lining and all the structural inequities that led to South Central being a place where Black low-income folks are concentrated." CADRE's political education helps participants understand the structural forces that have concentrated poverty and brought new immigrant communities to South LA, replacing the historic Black community.

Many organizers stress that solidarity can only be constructed on the basis of an analysis and strategy for change that understands and appreciates the root causes of systemic oppression. First of all, organizers believe that systems of oppression are linked. For example, Sally Lee says, "we see patriarchy, racism and capitalism as all fundamental roots of the problem. This makes us aligned on what we want to see in the world and our vision of what a just world looks like."

Within this linked system of oppression, most organizers name both systemic racism and economic exploitation as the central and twin causes. Carlos Rojas highlights economic exploitation in talking about how the privatization of public education is linked to attacks on teachers' unions: 
All the issues we're fighting about in education justice have everything to do with a very elegant scheme to bust one of the largest, still existent unions in the country, the teachers' unions, and to privatize public education. When we fight education justice issues, we fight it without looking at the larger picture that it's a part of a larger strategy by a group of people in this country to slowly divest from public education, promote private education pathways, and bust the teachers' union.

Based upon this analysis, Youth on Board pursues long-term, strategic partnerships with the region's teacher unions, combining strength in one case to pass an historic increase in funding for public education at the Massachusetts statehouse in 2020.

Several of the organizers emphasize the particular need to highlight anti-Black racism in creating solidarity across communities and issues. Maisie Chin emphasizes the importance of a shared analysis of anti-Black racism as the foundation for the South LA table discussed earlier. For Chin, criminalization of Black communities is the specific form that anti-Black racism and white supremacy takes today:

Criminalization is the connection between all these issues. It is precarious if you are criminalized. You don't get your healthcare. You won't get employed. They see you a certain way. Gentrification increases criminalization. To me, criminalization is an intersectional lens, period.

Not everyone spoke to anti-Black racism as central. Ricardo Martinez believes that understanding the root causes of systems that oppress both Black and Latino/a communities is key to solidarity because "it's the same fight against the same system. We have the same set of folks who are oppressing us and the same set of laws." Too often, in Martinez's view, there is a Black/white dichotomy where the historical oppression of Chicanos as conquered people in the Southwest and the racism towards them is not understood. At the same time, Martinez argues, "Chicanos have to understand that it's been easier for Chicanos to migrate into the white world than Blacks." In other words, while organizers share a broad analysis of intersectional root causes in economic, gender and racial oppression, there remain important conversations about the specific nature of these forms of oppression that impact solidarity-building processes.

\section{Building Trust through Long-term Commitments}

Strong relationships and shared understandings provide a foundation for solidarity but organizers say it is also necessary to demonstrate in practice a long-term commitment to groups other than your own. In other words, groups cannot always put their own organization or constituency first but must make sacrifices to support the movement as a whole. A first step is just to show up in support by attending the marches, rallies and events of other groups or coalitions. Yet even this physical presence is not so easy when groups have limited capacity and members are stretched for time. However, many organizers speak of the need to go further than showing up. Conscious leaders need to develop a long-term vision and a stake in each other's development so they understand that the success of other groups is essential to their movement as well. This commitment might mean stepping back and helping another group advance at any particular moment. Referencing the South LA Table, Chin says, "we roll out for the campaign actions of other groups," but "we do more. Because of our long-term vision, we understand when we need to build up other groups and when they need to build us up."

When groups act in the interests of the larger movement, they learn to trust other groups. This trust takes time and repeated interactions. In fact, all processes that create solidaritybuilding relationships, shared understandings, and trust - take time to develop. Speaking of the 
solidarity that was built across the LGBTQ youth and educational justice world, Geoffrey Winder of the GSA Network says, "we didn't create real solidarity within a year or two. It happened in year three, four, and five when LGBTQ youth started to become naturally included and were no longer an afterthought." Jonathan Stith from the Alliance for Educational Justice summarizes, "through collective work, collective struggle, and collective study of politics, we built really solid relationships."

\section{Critiques and Concerns about Intersectional Organizing}

Overall, organizers embrace intersectionality and intersectional organizing in the way we do: in the sense of appreciating that people are oppressed and respond along multiple lines of oppression (and therefore differently), centering the experiences and participation of those most impacted at intersecting forms of oppression, and building a truly inclusive movement. However, some organizers were critical of certain aspects of intersectionality, while others were concerned about the problematic ways that they see intersectional organizing being practiced that might undermine solidarity.

\section{Oppression Olympics}

Although many advocates of intersectional approaches explicitly reject creating an “oppression Olympics," (e.g., Hancock, 2011; E. Martinez, 1998), some organizers are concerned that intersectionality can lead to this kind of competition among people and groups for who is the most oppressed. There are concerns that this approach divides rather than unites groups, communities, and issues. Jonathan Stith worries that intersectional organizing can sometimes create an "inverse hierarchy" in movement spaces based solely on identity and not on training and skill level. As he states,

The oppression Olympics is real. There's this race to intersection, right? I am at all the intersections ...All my identities, check, check, check, so therefore I should be in leadership, right? [even if] unqualified. That's a contradiction because organizing doesn't actually respect any kind of hierarchy. Organizing is meant to disrespect hierarchy. And at the end of the day it doesn't necessarily build power.

Ricardo Martinez worries that intersectional theory places the focus on comparing oppressions that people face, which creates divisions. Rather, Martinez believes groups should work to unite around their forms of resistance. He says,

Chicanos were denied and lynched too — not as many in terms of numbers as Blacks_-but if we start to compare, and this is where the rough stuff comes in. If we start to compare who's most oppressed, then we lose. If we start to compare our acts of resistance and how do we join in that, that strengthens us.

\section{Class and Class-Based Unity}

Depending on how it is practiced, some organizers worry that intersectionality can prioritize certain forms of identity over a class analysis. Zakiya Sankara-Jabar argues that there are substantial class divisions within the Black community, and that organizers should not lose sight of class in movements. She shares,

One of the biggest wedges that we see that brings out the class issue is that there are some middle-class Blacks, including members of the local NAACP, like in Howard County, Maryland, that support police in schools. But many poor, working class families see the police as extremely oppressive and an occupying force in communities. 
Sally Lee believes that the language of intersectionality is not always helpful in targeting capitalism and appreciating systems of oppression. As she notes,

I don't use the word intersectionality because I associate it with, dare I say, identity politics, which kind of goes against my lived experience and my political understanding of capitalism in the world. I just think language fails us in trying to really comprehend humanity, and capitalism, and colonialism.

In other words, intersectionality can be a jargon term and it may make more sense to use terms that people can understand. Lee argues that many organizers have an implicit understanding that people and issues are complex, connected, and nuanced without having to stamp their work or their identities with the language of intersectionality. She notes that applying this terminology can "reduce people to a label," and further disaggregate people into an increasing number of separate categories.

Zakiya Sankara-Jabar also does not see the added value of using the term intersectionality. She believes that the Black community and the Black movement have always been interconnected and intergenerational, and those are the descriptive terms she prefers. She reflects:

I use interconnected because for me, historically in Black communities, our movements have been interconnected in many ways, have also been very intergenerational, where there's been young folks and also elders. There's always been Black women and Black men who organize together around issues and really lifting up the fact that we have to work together to protect our kids from these harmful institutions, education in particular. Similarly, while Ricardo Martinez describes the work of PJU as intersectional, he emphasizes their focus on community and intergenerational organizing. In other words, by intersectional organizing, some organizers mean organizing intergenerationally around family and community with a perspective that issues interconnect in people's lives.

\section{Discussion}

Intersectional analysis has contributed to a historic shift in social movements to include groups and people who had been previously silenced, displaced, and marginalized. We discovered that, perhaps unexpectedly, the assertion of voice and participation by those with identities marked by intersectional forms of oppression has also led to the development of groups organized around particular communities and issues, a process reinforced by the policies of private philanthropy and the siloed nature of political institutions. Consequently, the educational justice movement and other movements face the need to create solidarity across issues, communities, and other movements. Through this research, we have learned that crossmovement solidarity can refer to creating deep collaborations across groups focused on particular communities (African American, Latino/a, LGBTQ, and various intersectional identities) or focused on particular issues (education, gentrification, or climate justice), or some combination of the two (Black parents organizing to stop school closings in gentrifying communities).

We found that organizers in the educational justice movement center people most impacted by educational injustice and deeply appreciate the intersectional nature of the issues facing their lives. Organizers, in principle, appreciate the dictum from Audre Lorde (2007) that people don't live single issue lives, so movements should not organize single issue campaigns. However, groups face important obstacles to implementing this approach, including low resources, the demands of foundation funding, and the siloed nature of the political institutions 
they are targeting with their demands. If groups with few resources want to create policy change in the near run, they feel the need to focus on and target single issues.

We also found that organizers in the educational justice movement deeply appreciate the need to create solidarity across groups representing different constituencies or identities. Intersectional analysis, as we have defined it, can partially help to build this kind of solidarity. It highlights the need for solidarity based upon an appreciation of the different experiences and needs of those facing multiple forms of oppression, provides a resource for challenging power and privilege so that solidarity is inclusive and democratic, and suggests that solutions created to meet the needs of those at the intersections will support the needs of all communities. In principle, centering people whose identities cross communities should help connect them, as Black women might connect the African American and women's movements. Yet many organizers worry that intersectional analysis - despite the views of founders Crenshaw and Collins who saw intersectionality as an inclusive force-might narrow the movement to the most marginalized or to those who already share their analysis. They also worry it might create an "oppression Olympics" resulting in competition between communities to establish who is the most oppressed.

Despite these concerns and the pressures towards siloing, we found deep appreciation and many examples of efforts to use intersectional organizing and other processes to create new forms of solidarity in the educational justice movement. Our findings align with those of Veronica Terriquez who has shown that many youth organizing groups in the education movement are multi-issue, reflecting the intersecting nature of the systems of oppression and issues facing youth of color, including immigrant youth and queer and trans youth of color (Terriquez, 2015; Terriquez \& Lin, 2020). Within our study, groups like PJU in Denver and the Latino/a Roundtable in Los Angeles County practice intergenerational and multi-issue organizing even as they often center educational justice; the GSA Network also addresses multiple issues facing trans and queer youth. In addition, every group represented in this study has undertaken serious efforts to build solidarity through coalitional work across issues and movements within and beyond educational justice. We have learned from the organizers that intersectional organizing can support cross-movement solidarity especially when combined with other processes, including building deep relationships, developing conscious leadership with shared understandings of systemic oppression through political education, and building trust through demonstrated long-term commitments to solidarity in practice.

Nevertheless, several organizers articulate a somewhat different approach than what we mean by intersectionality, which is centering people who experience multiple lines of oppression. Although they do not necessarily reject intersectionality, they emphasize interconnectedness - the connections across issues in the lives of people in community. Interconnectedness as an analytical framework has much in common with intersectionality. Interconnectedness suggests that lines of oppression intersect in people's lives and appreciates the different experiences and identities people have due to particular ways that the lines of oppression intersect. These organizers fear divisiveness and value community unity; they want to include everyone and address particular needs, but do not necessarily prioritize centering the experiences and leadership of those who experience multiple lines of oppression or could be positioned as "the most oppressed of all." 


\section{Conclusion}

Organizing groups and movements within and beyond educational justice are weaker to the extent that they remain siloed. Their agendas and their power remain limited, as fighting school closings without also fighting the gentrification and displacement of communities that the schools serve, for example, may be a losing proposition in the long run for both movements. Intersectional organizing has become something of a buzzword to capture the sentiment of solidarity, which in reality requires conscious, sustained efforts to build.

Education is not simply one issue in the interconnected lives of students and families, and it is not simply one line of oppression among many. It is a key democratic institution and has been a vital force for the liberation of peoples, as in the Freedom Schools of the Civil Rights Movement (Payne \& Strickland, 2008). Organizers recognize the current role of public schools as a force of oppression, but many also speak to the potential for education as a space for intersectional liberation and a key entry point for larger movement building. In Jonathan Stith's view:

Public education offers a transformative ground, transforming the space to begin to think about and to reimagine the society that we want to see. We can begin that really concrete work in schools. That's our education revolution. If we transform decadent education, does that create the space and the power to transform society? So we see education as the intersectional space from which we all organize to transform society. 


\section{References}

Anzaldúa, G. (1987). Borderlands/La frontera: The new Mestiza. Aunt Lute Books.

Boyatzis, R. E. (1998). Transforming qualitative information: Thematic analysis and code development. Sage.

Buras, K. L. (2014). Charter schools, race, and urban space: Where the market meets grassroots resistance. Routledge.

Cohen, C. J. (1999). The boundaries of blackness: AIDS and the breakdown of Black politics. University of Chicago Press.

Collins, P. H. (2000). Black feminist thought: Knowledge, consciousness, and the politics of empowerment (2nd ed.). Routledge.

Collins, P. H. (2019). Intersectionality as critical social theory. Duke University Press.

Collins, P. H., \& Bilge, S. (2016). Intersectionality. Polity Press.

Combahee River Collective. (1986). The Combahee River Collective Statement: Black feminist organizing in the seventies and eighties. Kitchen Table.

Crenshaw, K. W. (1990). Mapping the margins: Intersectionality, identity politics, and violence against women of color. Stanford Law Review, 43, 1241-1299.

Ewing, E. L. (2018). Ghosts in the schoolyard: Racism and school closings on Chicago's South Side. University of Chicago Press.

Fine, M. (2018). Just research in contentious times: Widening the methodological imagination. Teachers College Press.

Fine, M., White, L., Pruitt, L. P. P., \& Burns, A. (2012). Off-white: Readings on power, privilege, and resistance. Routledge.

Garza, A. (2014). A herstory of the\# BlackLivesMatter movement. In J. Hobson (Ed.), Are all the women still white (pp. 23-28). SUNY Press.

Hancock, A.-M. (2011). Solidarity politics for millennials: A guide to ending the oppression Olympics. Palgrave-Macmillan.

Jackson, S. J. (2016). (Re)imagining intersectional democracy from Black feminism to hashtag activism. Women's Studies in Communication, 39(4), 375-379.

Journey for Justice Alliance. (2014). Death by a thousand cuts: Racism, school closures, and public school sabotage. Retrieved October 1, 202 from

https://dignityinschools.org/resources/death-by-a-thousand-cuts-racism-school-closuresand-public-school-sabatoge/.

Kunreuther, F., \& Thomas-Breitfeld, S. (2015). The new now: Working together for social change. Retrieved October 1, 2020 from https://buildingmovement.org/reports/the-newnow-working-together-for-social-change/.

Lindsey, T. B. (2015). Post-Ferguson: A "herstorical" approach to Black violability. Feminist Studies, 41(1), 232-237.

Lipman, P. (2011). The new political economy of urban education: Neoliberalism, race and the right to the city. Routledge.

Lorde, A. (2007). Learning from the 60s. In A. Lorde (Ed.), Sister outsider: Essays and speeches by Audre Lorde (pp. 134-144). Crossing Press.

Martinez, E. (1998). De Colores means all of us: Latina views for a multi-colored century. South End Press.

Martinez, P. (2018). The freedom to learn: Dismantling the school-to-prison pipeline in the Southwest. In M. R. Warren (Ed.), Lift Us Up, Don't Push Us Out! Voices from the front lines of the educational justice movement (pp. 36-45). Beacon Press. 
Milkman, R. (2017). A new political generation: Millennials and the post-2008 wave of protest. American Sociological Review, 82(1), 1-31.

Morris, M. (2018). Pushout: The criminalization of Black girls in school. The New Press.

Payne, C. M., \& Strickland, C. S. (2008). Teach freedom: Education for liberation in the African-American tradition. Teachers College Press.

Rickford, R. (2016). Black lives matter: Toward a modern practice of mass struggle. New Labor Forum, 25(1), 34-42.

Ritchie, A. (2017). Invisible no more: Police violence against black women and women of color. Beacon Press.

Terriquez, V. (2015). Intersectional mobilisation, social movement spillover, and queer youth leadership in the immigrant rights movement. Social Problems, 62(3), 343-362.

Terriquez, V., Brenes, T., \& Lopez, A. (2018). Intersectionality as a multipurpose collective action frame: The case of the undocumented youth movement. Ethnicities, 18(2), 260276.

Terriquez, V., \& Lin, M. (2020). Yesterday they marched, today they mobilised the vote: a developmental model for civic leadership among the children of immigrants. Journal of Ethnic and Migration Studies, 46(4): 747-769.

Teuscher, A. (2015). The inclusive strength of \#BlackLivesMatter. The American Prospect. Retrieved from https://prospect.org/article/inclusive-strength-blacklivesmatter

Warren, M. R. (2018). Lift us up Don't push us out! Voices from the front lines of the educational justice movement. Beacon Press.

Wilson, E. K. (2015). Gentrification and urban public school reforms: The interest divergence dilemma. West Virginia Law Review, 118(2), 677-733. 


\section{Appendix A}

\section{List of Interviews}

\section{Organizers interviewed:}

- Natasha Capers, Coalition for Educational Justice

- Maisie Chin, CADRE

- Sally Lee, Teachers Unite

- Ricardo Martinez, Padres \& Jóvenes Unidos

- Kate McDonough, Girls for Gender Equity (now Dignity in Schools Campaign NYC)

- Carlos Rojas, Youth on Board

- Zakiya Sankara-Jabar, Dignity in Schools Campaign (formerly Racial Justice NOW!)

- Jonathan Stith, Alliance for Educational Justice

- Geoffrey Winder, Genders \& Sexualities Alliance Network

- Jose Calderon, Latino/a Roundtable of the San Gabriel Valley and Pomona Valley 


\section{Appendix B Interview Questions}

1. How do your own personal identities and experiences influence how you organize?

a. How about the issues you organize around?

2. Do you use the term intersectional organizing in your work? What do you mean by intersectional organizing?

3. What do you see as the key issues that intersect with your educational work?

4. Does your group pursue intersectional organizing strategies?

a. If not, why not.

b. If so, tell us about it.

i. How do you do it? Prompt for specific examples

ii. Under what conditions are you more likely to do it?

c. What do you see as the benefits of taking an intersectional approach?

d. What are the downsides or challenges to taking an intersectional approach?

e. How would the educational justice movement need to change to be more intersectional?

5. Some people say that intersectionality means centering the lived experiences of people who are at the intersection of multiple systems of oppressions.

a. Have you thought about that?

b. If not, what do you think of that approach?

c. If you were to develop strategies that focus on the lived experience of low-income youth of color, and took into consideration intersectional experiences for immigrant youth of color, by gender and for LGBTQ and gender-non-conforming youth, what would that look like?

d. What are the obstacles to taking this approach?

6. We're interested in whether intersectional strategies help build solidarity across issues and movements.

a. In what ways has the educational justice movement created solidarity with other movements and vice versa?

b. What else needs to be done to build stronger solidarity across movements?

c. To what extent can the struggle for educational justice be the connector between movements?

d. Do intersectional strategies help us think about solidarity in new ways?

7. If not already mentioned, is there anyone special you think we should interview to learn more about intersectional organizing?

a. Is there any particular group or work to investigate that you think stands out as intersectional organizing?

8. Is there anything else you want to add that you haven't had the chance to share? 